\title{
PENGARUH CITRA MEREK DAN KUALITAS PELAYANAN TERHADAP KEPUASAN NASABAH PT PEGADAIAN (PERSERO) BATAM
}

\author{
${ }^{1}$ Syaifullah ${ }^{2}$ Mira \\ ${ }^{1}$ Universitas Putera Batam \\ syaifullah2929@gmail.com
}

\begin{abstract}
The purpose of research is to know the partial influence ( $T$ test) and simultaneously ( $F$ test) between brand image variable and service quality to customer satisfaction PT Pegadaian (Persero) Batam. The research method used in this research is descriptive research method with quantitative approach Data collection techniques were done by distributing questionnaires to each respondent as much as 294 respondents. The results showed that the value of $R$ Square of 0,135 or 13,5\% of the value can be known the brand image and service quality affect the customer satisfaction of 13,5\% while the rest is $86,5 \%$ influenced by other factors not examined. The result of research based on $t$ test for brand image has value equal to 6,080 > 1,968 ( $t$ table) and significant value 0,000<0,05 meaning that variable of brand image have significant effect to customer satisfaction, while service quality has value of 2,281 > 1,968 ( $t$ table) and significant value 0,023<0,05 meaning service quality variable have significant effect to customer satisfaction. And the result of $F$ test has value equal to 22,670>3,03 ( $F$ table) and significant value 0,000<0,05 can be interpreted that variable brand image and service quality simultaneously have significant effect toeffect to customer satisfaction.
\end{abstract}

Keywords: Brand Image, Service Quality, Customer Satisfaction

\begin{abstract}
ABSTRAK
Tujuan penelitian adalah untuk mengetahui pengaruh parsial (uji t) dan secara simultan (uji F) antara variabel citra merek dan kualitas layanan terhadap kepuasan pelanggan PT Pegadaian (Persero) Batam. Metode penelitian yang digunakan dalam penelitian ini adalah metode penelitian deskriptif dengan pendekatan kuantitatif Teknik pengumpulan data dilakukan dengan menyebarkan kuesioner kepada setiap responden sebanyak 294 responden. Hasil penelitian menunjukkan bahwa nilai R Square sebesar 0,135 atau $13,5 \%$ dari nilai dapat diketahui citra merek dan kualitas layanan berpengaruh terhadap kepuasan pelanggan sebesar $13,5 \%$ sedangkan sisanya sebesar $86,5 \%$ dipengaruhi oleh faktor lain tidak diperiksa. Hasil penelitian berdasarkan uji t untuk citra merek memiliki nilai sebesar 6,080> 1,968 ( $\mathrm{t}$ tabel) dan nilai signifikan $0,000<0,05$ yang berarti bahwa variabel citra merek berpengaruh signifikan terhadap kepuasan pelanggan, sedangkan kualitas layanan memiliki nilai 2,281>1,968 (ttabel) dan nilai signifikan $0,023<0,05$ yang berarti variabel kualitas pelayanan berpengaruh signifikan terhadap kepuasan pelanggan. Dan hasil uji F memiliki nilai sebesar 22,670> 3,03 (F tabel) dan nilai signifikan $0,000<0,05$ dapat diartikan bahwa citra merek variabel dan kualitas layanan secara simultan berpengaruh signifikan terhadap kepuasan pelanggan.
\end{abstract}

Kata Kunci: Citra Merek, Kualitas Layanan, Kepuasan Pelanggan

\section{PENDAHULUAN}

Salah satu upaya pemerintah untuk menyehatkan perekonomian nasional adalah dengan cara penyaluran dana dalam bentuk kredit. Kredit tersebut dapat diberikan kepada masyarakat atau wirausahawan yang memerlukan. Batam sebuah kota yang sangat dekat dengan Negara tetangga seperti Singapore dan Malaysia, ini menjadi alasan perekonomian masyarakat Batam yang selalu tinggi, seperti harga bahan pokok dan biaya hidup lainnya. 
Untuk mencukupi biaya hidup beberapa orang memutuskan untuk menggadaikan barang berharganya seperti emas, kendaraan, barang eletronik seperti TV LCD, Kamera serta Hanphone.

Pegadaian syariah merupakan jaminan utang atau gadai. Meskipun penggadaian syariah sangat berperan di masyarakat namun pegadaian juga harus menjaga citra baik dari pada penggadaian itu sendiri dan meningkatkan kualitas pelayanan terhadap nasabah sehingga nasabah akan merasa puas.

Masalah citra merek di pegadaian syariah cabang simpang kara Batam adalah ditandai dengan adanya penurunan produk mulia yang mana sebelumnya produk ini sangat diminati oleh nasabah. Tetapi, karena adanya kesalahan yang mengakibatkan terjadinya penurunan keinginan nasabah pada produk tersebut. Masalah Kualitas Pelayanan di PT Pegadaian Syariah cabang Simpang Kara Batam adalah belum adanya manajerial yang ideal seperti lembaga keuangan lainnya sehingga lembaga tersebut masih kurang optimal dalam melayani kebutuhan masyarakat, misalnya kurangnya toilet untuk nasabah dan kurangnya vasilitas tempat parkir bagi nasabah.

Berdasarkan latar belakang diatas, maka permasalahan yang akan diteliti dapat dirumuskan sebagai berikut: (1) Apakah citra merek berpengaruh terhadap kepuasan nasabah PT. Pegadaian (Persero) Batam? (2) Apakah kualitas pelayanan berpengaruh terhadap kepuasan nasabah PT. Pegadaian (Persero) Batam? (3) Apakah citra merek dan kualitas pelayanan berpengaruh terhadap kepuasan nasabah PT. Pegadaian (Persero) Batam?

Berdasarkan latar belakang masalah dan rumusan masalah diatas, maka penelitian ini bertujuan: (1) Untuk mengetahui pengaruh variabel citra merek terhadap kepuasan nasabah PT. Pegadaian (Persero)
Batam. (2) Untuk mengetahui pengaruh variabel kualitas pelayanan terhadap kepuasan nasabah PT. Pegadaian (Persero) Batam. (3) Untuk mengetahui pengaruh variabel citra merek dan kualitas pelayanan terhadap kepuasan nasabah PT. Pegadaian (Persero) Batam.

\section{LANDASAN TEORI \\ Citra Merek}

Menurut Aasker dalam (Sangadji \& Sopiah, 2013:327-328) Citra merek adalah seperangkat asosiasi unik yang ingin diciptakan atau dipelihara oleh pemasar.

Menurut (Simanora, 2008:33) terdapat indicator untuk mengukur citra merek sebagai berikut:

1.Citra pembuat (corporate image)

2.Citra pemakai (user image)

3 Citra Produk (product image)

\section{KualitasPelayanan}

Menurut (Ellitan \& Anatan, 2009:117) Kualitas pelayanan merupakan tingkat keunggulan yang diharapkan dan pengendalian tingkat keunggulan untuk memenuhi keinginan pelanggan.

Menurut (Tjiptono, 2008:108) terdapat indicator dalam mengukur kualitas pelayanan adalah sebagai berikut:

1. Bukti fisik (tangibles)

2. Keandalan (reliability)

3.Ketanggapan (responsiveness)

4.Jaminandan kepastian (assurance)

5. Empati (empathy)

KepuasanNasabah

Menurut Kotler dalam (Sentot Imam wahjono,2010:18) menyatakan bahwa kepuasan pelanggan adalah perasaan senang atau kekecewaan seseorang setelah membandingkan kinerja atau hasil yang dirasakan dibandingkan dengan harapannaya.

Menurut (Irwan, 2009: 3) pengukuran kepuasan pelanggan dapat dilakukan sebagai berikut: 
1. Perasaan puas

2. Selalu membeli produk

3. Akan merekomendasikan kepada orang lain

4. Terpenuhinya harapan pelanggan setelah memberli produk

\section{Hipotesis}

Menurut (Sugiyono, 2015:99) hipotesis merupakan jawaban sementara terhadap rumusan masalah penelitian, dimana rumusan masalah penelitian telah dinyatakan dalam bentuk kalimat pertanyaan. Hipotesis dalam penelitian ini adalah sebagai berikut :

H1: Diduga citra merek berpengaruh positif dan signifikan terhadap kepuasan nasabah PT Pegadaian (Persero).

H2:Diduga kualitas pelayanan berpengaruh positif dan signifikan terhadap kepuasan nasabah PT Pegadaian (Persero).

H3:Diduga citra merek dan kualitas pelayanan berpengaruh positif dan signifikan terhadap kepuasan nasabah PT Pegadaian (Persero).

\section{METODE PENELITIAN \\ Populai Dan Sampel}

Menurut (Sugiyono, 2015:119) populasi merupakan wilayah generalisasi yang terdiri atas obyek yang mempunyai kualitas dan karakteristik tertentu yang ditetapkan oleh peneliti untuk dipelajari dan kemudian ditarik kesimpulannya. Populasi dalam penelitian ini adalah nasabah aktif di PT Pegadaian (Persero) yang berjumlah 1108 orang.

Menurut (Sugiyono, 2015:120) sampel merupakan bagian dari jumlah dan karakteristik yang dimiliki oleh populasi tersebut. Pengambilan sampel pada penelitian ini menggunakan rumus slovin dengan tingkat kesalahan 5\% $(0,05)$, sehingga jumlah sampel pada penelitian ini adalah sebanyak 294 responden.

\section{Analisis Deskriptif}

Menurut

(Wibowo,

2012:24)

analisis deskriptif atau statistik deskriptif merupakan

statistik yang menjelaskan suatu data yang telah dikumpulkan dan diringkas pada aspek- aspek penting berkaitan dengan data tersebut.

\section{Uji Validitas Data}

Menurut (Wibowo, 2012:35) Uji validitas digunakan untuk mengetahui sejauh mana alat pengukur itu mampu mengukur apa yang ingin diukur. Dari uji validitas kita dapat mengetahui apakah item-item pertanyaan yang diajukan dalam kuesioner dapat digunakan untuk mengukur keadaan responden yang sebenarnya dan menyempurnakan kuesioner tersebut. Keputusan untuk uji validitas sebagai berikut:

a. Jika $\mathrm{r}$ hitung $>\mathrm{r}$ tabel, maka dikatakan valid

b. Jika $\mathrm{r}$ hitung $<\mathrm{r}$ tabel, maka dikatakan didak valid

\section{Uji Reliabilitas}

Menurut (Wibowo, 2012:52-53) uji reliabilitas dipakai untuk menunjukkan sejauh mana suatu hasil pengukuran relatif konsisten apabila pengukuran diulangi dua kali atau lebih. Uji ini digunakan untuk mengetahui dan mengukur tingkat konsistensi alat ukur. Menggunakan batasan 0,6 dapat ditentukan apakan instrumenn reliabel atau tidak. Reliabilitas kurang dari 0,6 adalah cukup, sedangkan 0,7 tinggi, dan diatas 0,8 adalah sangat tinggi.

\section{Uji normalitas}

Menurut (Wibowo, 2012:61) uji normalitas digunakan untuk mengetahui apakah nilai residu (perbedaan yang ada) yang diteliti memiliki distribusi normal atau tidak normal. Nilai risidu yang berdistribusi normal akan membentuk suatu kurva 
yang kalau digambarkan akan berbentuk lonceng (bell shaped curve).

Uji normalitas dapat dilakukan dengan menggunakan Histogram Regression Residual yang sudah distandarkan, Menurut (Wibowo, 2012:72) data yang diuji dalam uji normalitas akan dibuktikan normalitasnya dengan menggunakan uji Kolmogorov- smirnov. Jika nilai Probability Sig (2 tailed)

$>\alpha ; \operatorname{sig}>0,05$.

\section{HASIL DAN PEMBAHASAN}

\section{Hasil Uji Validitas}

Hasil uji validitas adalah sebagai berikut:

Tabel 3 Uji Validitas Variabel Citra Merek (X1)

\begin{tabular}{cccc}
\hline Pernyataan & r hitung $(>)$ & r tabel & Keterangan \\
\hline $\mathrm{X} 1 \_1$ & 0,768 & 0,114 & Valid \\
$\mathrm{X} 12$ & 0.812 & 0.114 & Valid \\
\hline $\mathrm{X} 1 \_3$ & 0,836 & 0,114 & Valid \\
\hline
\end{tabular}

Tabel 4 Uji Validitas Variabel Kualitas Pelayanan (X2)

\begin{tabular}{cccc}
\hline Pernyataan & r hitung $(>)$ & r tabel & Keterangan \\
\hline X2_1 & 0,681 & 0,114 & Valid \\
X2_2 & 0,547 & 0,114 & Valid \\
X2_3 & 0,582 & 0,114 & Valid \\
X2_4 & 0,777 & 0,114 & Valid \\
\hline X2_5 & 0,581 & 0,114 & Valid \\
\hline
\end{tabular}

Tabel 5 Uji Validitas Variabel Kepuasan Nasabah (Y)

\begin{tabular}{cccc}
\hline Pernyataan & r hitung $(>)$ & r tabel & Keterangan \\
\hline Y_1 & 0,719 & 0,114 & Valid \\
Y_2 & 0,743 & 0,114 & Valid \\
Y_3 & 0,746 & 0,114 & Valid \\
Y_4 & 0,765 & 0,114 & Valid \\
\hline
\end{tabular}

\section{Hasil Uji Regresi Linear Berganda}

Tabel 12 Regresi Linear Berganda

\begin{tabular}{|c|c|c|c|c|c|c|}
\hline \multirow[b]{3}{*}{ Mode } & \multicolumn{2}{|c|}{ Unstandardized } & & \multicolumn{2}{|l|}{ Standardized } & \multirow{3}{*}{ Sig } \\
\hline & & & Coefficients & Coefficients & $\mathrm{T}$ & \\
\hline & & B & Std. Error & Beta & & \\
\hline \multirow[t]{3}{*}{1} & (Constant) & 4.171 & 1.968 & & 2.120 & .035 \\
\hline & $\begin{array}{l}\text { Citra Merek } \\
\text { (X1) }\end{array}$ & .400 & .066 & .333 & 6.080 & .000 \\
\hline & $\begin{array}{l}\text { Kualitas } \\
\text { Pelayanan(X }\end{array}$ & .250 & .110 & .125 & 2.281 & .023 \\
\hline
\end{tabular}


Berdasarkan hasil uji regresi

linear berganda di dapat dari persamaan:

$$
\mathrm{Y}=4,171+0,400 \mathrm{X}_{1}+0,250 \mathrm{X}_{2}
$$

1. Konstanta memiliki nilai sebesar 4,171 artinya jika variabel indevenden terdiri dari X1 (Citra Merek) dan X2 (Kualitas Pelayanan) dianggao 0 (nol) atau tidak diterapkan, maka Y (Kepuasan Nasabah) memiliki nilai 4,171 satuan.

2. Variabel X1 (Citra Merek) memiliki nilai koefisien regresi sebesar 0,400. Ini berarti jika citra merek ditingkatkan sebesar 1 skala dalam jawaban responden maka akan meningkatkan kepuasan nasabah pegadaian sebesar

0,400 satuan dengan asumsi faktorfaktor lain dianggap tetap.

3. Variabel X2 (Kualitas Pelayanan) memiliki nilai koefisien regresi sebesar

0,250. Ini berarti jika kualitas pelayanan ditingkatkan sebesar 1 skala dalam jawaban responden maka akan meningkatkan kepuasan nasabah pegadaian sebasar 0,250 satuan dengan asumsi variabel lain dianggap tetap.

\section{Hasil Uji T}

uji t digunakan untuk mengetahui apakah variabel independen berpengaruh signifikan terhadap variabel dependen.

Tabel 14 Uji T

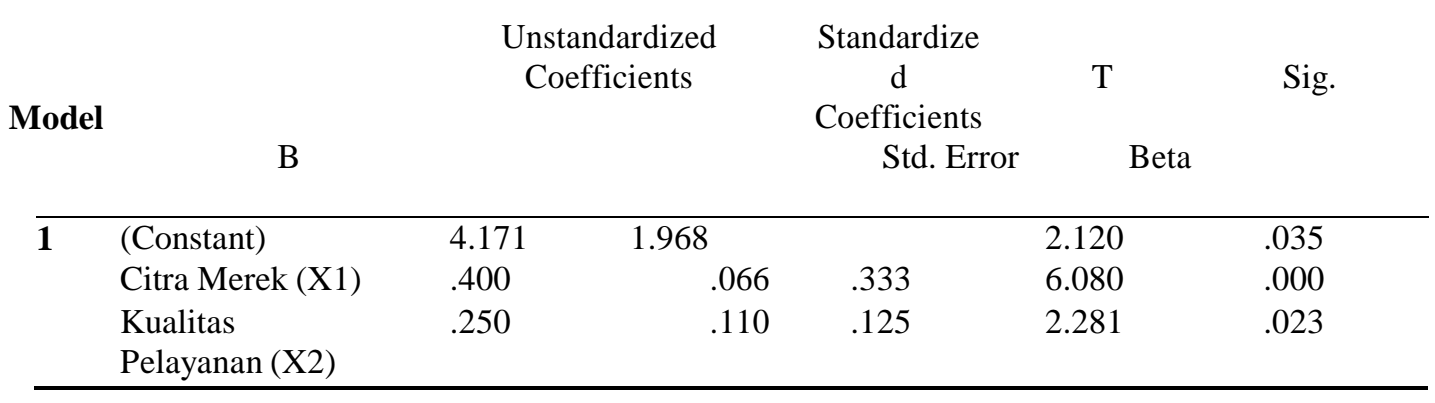

\section{Hasil Uji F}

Tabel 15 Uji F kecil dari nilai alpha 0,05. Maka dapat disimpulkan bahwa citra merek berpengaruh positif dan signifikan

\begin{tabular}{|c|c|c|c|c|}
\hline Model & & $\begin{array}{l}\text { Sum of } \\
\text { Sowares }\end{array}$ & Df & $\begin{array}{l}\text { Metrhadap kfpuasan 1Sigabah di PT } \\
\text { SamRegadaian (Persero) Batam. }\end{array}$ \\
\hline & Regression & 279.697 & 2 & 139284 Berd2sat 679 hasil penelit \\
\hline & & 1795. & 29 & 1 kualitas nilai $t$ hitung sebesar \\
\hline & Total & 2074.803 & 293 & lebih hesar dishanding t tab \\
\hline
\end{tabular}

\section{KESIMPULAN}

Kesimpulan sebagai berikut:

1. Berdasarkan hasil penelitian pada variabel citra merek nilai $t$ hitung sebesar 6,080 lebih besar dibanding dengan $\mathrm{t}$ tabel sebesar 1,968. Dikatakan signifikan karena nilai signifikan dari variabel citra merek sebesar 0,000 lebih sebesar 1,968. Dikatakan signifikan karena nilai signifikan dari variable kualitas pelayanan 0,023 lebih kecil dari nilai alpha 0,05. Maka dapat disimpulkan bahwa kualitas pelayanan berpengaruh positif dan signifikan terhadap kepuasan nasabah di PT Pegadaian (Persero) Batam. 3.Berdasarkan hasil penelitian pada variabel citra merek dan kualitas 
pelayanan terhadap kepuasan nasabah dilihat dari hasil uji $\mathrm{F}$ yaitu 22,670 (F hitung) > 3.03 (F tabel) dan Signifikan sebesar $0,000<0,05$ (alpha). Maka dapat disimpulkan bahwa variabel citra merek dan kualitas pelayanan secara bersama-sama berpengaruh signifikan terhadap kepuasan nasabah.

\section{DAFTAR PUSTAKA}

Alma, B. (2011). Manajemen pemasaran dan Pemasaran jasa. bandung: Alfabeta.

Ellitan, L., \& Anatan, L. (2009). Sistem informasi manajemen konsep dan praktis. Bandung: ALFABETA.

Fakhrudin, A. (2016). analisis pengaruh kualitas pengaruh terhadap kepuasan, 9,

$72-$

83.

Irwan, H. (2009). 10 Prinsip Kepuasan Pelanggan. jakarta: Elex Media Komputindo.

Kotler, P. (2009). Manajemen pemasaran. jakarta: Erlangga.

Kotler, P., \& Keller, K. L. (2009).

Manajemen Pemasaran. (A. Maulana \& Y. S. Hayati, Eds.) (Edisi 13 J). jakarta: Erlangga.

nazir. (2011). metode penelitian. bogor: Ghalia.

Ofela, H. (2016). Pengaruh harga, kualitas produk dan kualitas pelayanan terhadap kepuasan konsumen kebab kingabi, 5, 115.

Priyatno, D. (2008). MANDIRI BELAJAR SPSS ( Statistical Product and Service Solution ) untuk Analisis Data \& Uji

Statistik. Bandung: mediakom.
Priyatno, D. (2010). Paham Analisa Statistik Data dengan SPSS: Plus Tata Cara dan Tips Menyusun Skripsi dalam Waktu

Singkat. Bandung: mediakom.

Sangadji, E. M., \& Sopiah. (2013). Perilaku Konsumen- pendekatan praktis disertai himpunan jurnal penelitian. (N. WK, Ed.). Yogyakarta: ANDI OFFSET. Sanusi, A. (2011). Metodologi Penelitian BISNIS. jakarta: Salemba Empat. imanora, B. (2008). Memenangka Pasar

$\begin{array}{lrr}\text { dengan } & \text { Pemasaran } & \text { Efektif } \\ \text { dan } & & \\ \text { Profitabel. } & \text { Jakarta: } & \text { PT. } \\ \text { Gramedia } & & \\ \text { Pustaka } & & \\ \text { Utama. } & & \end{array}$

Sugiyono. (2012). Metode Penelitia Kuantitatif, Kualitatif dan $R \& D$. Bandung: CV. ALFABETA.

Sugiyono. (2015). Metode Penelitian Kuantitatif, Kualitatif dan Kombinasi (mixed methods). (Sutopo, Ed.). Bandung: CV. ALFABETA.

Sukamma, L. E., \& Muthalib, A. (2014).

Pengaruh Kualitas Pelayanan Terhadap Kepuasan Nasabah PT. Pegadaian (Persero) Cabang Madala Medan. Jurnal

Ilmu Administrasi

Publik.

Suyanto, D. (2013). TEORI, KUESIONER \& ANALISIS DATA untuk pemasaran dan perilaku konsumen (pertama). Yogyakarta: Graha ilmu. 